\title{
Differentiation and Function of Follicular CD8 T Cells During Human Immunodeficiency Virus Infection
}

\author{
Minglu Xiao ${ }^{1}$, Xiangyu Chen ${ }^{1}$, Ran $\mathrm{He}^{2 *}$ and Lilin Ye ${ }^{1 *}$ \\ ${ }^{1}$ Institute of Immunology, Third Military Medical University, Chongqing, China, ${ }^{2}$ Department of Immunology, School of Basic \\ Medicine, Huazhong University of Science and Technology, Wuhan, China
}

OPEN ACCESS

Edited by:

Vijayakumar Velu,

Emory University,

United States

Reviewed by:

Elizabeth Connick,

University of Arizona,

United States

Amitinder Kaur,

Tulane University,

United States

Stuart G. Tangye,

Garvan Institute of Medical

Research, Australia

${ }^{*}$ Correspondence:

$\mathrm{Ran} \mathrm{He}$

ranhe@hust.edu.cn;

Lilin Ye

yelilinlcmv@tmmu.edu.cn

Specialty section:

This article was submitted to Viral Immunology, a section of the

journal Frontiers in Immunology

Received: 22 February 2018

Accepted: 02 May 2018

Published: 22 May 2018

Citation:

Xiao M, Chen X, He R and Ye L (2018) Differentiation and Function of Follicular CD8 T Cells During Human Immunodeficiency Virus Infection.

Front. Immunol. 9:1095. doi: 10.3389/fimmu.2018.01095
The combination antiretroviral therapeutic (CART) regime effectively suppresses human immunodeficiency virus (HIV) replication and prevents progression to acquired immunodeficiency diseases. However, cART is not a cure, and viral rebound will occur immediately after treatment is interrupted largely due to the long-term presence of an HIV reservoir that is composed of latently infected target cells that maintain a quiescent state or persistently produce infectious viruses. CD4 T cells that reside in B-cell follicles within lymphoid tissues, called follicular helper T cells (TFH), have been identified as a major HIV reservoir. Due to their specialized anatomical structure, HIV-specific CD8 T cells are largely insulated from this TFH reservoir. It is increasingly clear that the elimination of TFH reservoirs is a key step toward a functional cure for HIV infection. Recently, several studies have suggested that a fraction of HIV-specific CD8 T cells can differentiate into a CXCR5-expressing subset, which are able to migrate into B-cell follicles and inhibit viral replication. In this review, we discuss the differentiation and functions of this newly identified CD8 T-cell subset and propose potential strategies for purging TFH HIV reservoirs by utilizing this unique population.

Keywords: follicular CD8 T cells, B-cell follicles, human immunodeficiency virus infections, human immunodeficiency virus reservoir, CXCR5 ${ }^{+}$CD8 T cells

\section{INTRODUCTION}

Human immunodeficiency virus (HIV)-specific CD8 T cells play an important role in suppressing HIV replication (1-5). The onset of HIV-specific CD8 T cell responses is concomitant with a reduction in plasma viremia (6-8). The rapidity and magnitude of HIV-specific CD8 T-cell responses correlate inversely with set-point viremia in hyperacutely infected patients (9). However, diminished HIV-specific CD8 T cell responses are accompanied by disease progression (10). Furthermore, elite controllers of HIV infection exhibit specific major histocompatibility complex (MHC) class I alleles and a wide spectrum of HIV-specific CD8 T-cell responses (11-15). Additionally, CD8 T cell-specific epitope mutants emerge to evade CD8 T-cell recognition during HIV infection $(16,17)$. Most direct evidence comes from rhesus macaques with chronic simian immunodeficiency virus (SIV) infection, in which transient CD8 $\mathrm{T}$ cell depletion resulted in a substantial increase in plasma viremia, while the subsequent replenishment of CD8 T cells led to a reduction in viremia (18-20). Despite the importance of HIV-specific CD8 T cells, they are not capable of fully eliminating HIV-infected target cells, mainly CD4 T cells. A wide variety of extrinsic and intrinsic factors are required to cripple HIV-specific CD8 T-cell mediated inhibition of HIV replication. One key factor lies in the functional exhaustion of HIV-specific CD8 T cells due to persistent T-cell receptor (TCR) stimulation and inhibitory microenvironments (21-23). Additionally, recent progress has been made to realize that HIV preferentially targets TFH cells in B-cell follicles for both long-term latent infection and the persistent production of infectious viral particles (24-28), and the majority of HIV-specific CD8 
T cells are excluded from B-cell follicles (29-31). Therefore, the exhaustion of HIV-specific CD8 T cells and the anatomical separation of latently infected TFH cells and HIV-specific CD8 T cells might represent two primary barriers for HIV-specific CD8 $\mathrm{T}$ cells to eradicate HIV infection. Combination antiretroviral therapeutic (cART) is extremely effective at decreasing viremia to an undetected level (32-34); however, the viremia rebounds soon after the cessation of treatment (35-37). These facts further suggest that exhausted HIV-specific CD8 T cells cannot efficiently inhibit residual viral replication in the presence of effective cART treatment. However, a small fraction of CD8 T cells has been discovered to appear in B cell follicles in HIV infection as early as 1980 and 1990s (38-43). In 2007, Quigley et al. also reported that early effector memory CXCR $5^{+} \mathrm{CD} 8 \mathrm{~T}$ cells infiltrated into $\mathrm{B}$ cell follicles in human tonsil (44). Until recently, several groups reported a novel subset of exhausted HIV-specific CD8 T cells expressing CXCR5 and capable of migrating to B-cell follicles during HIV/SIV infection that rekindled interest in the filed (45-54). In this review, we focus on understanding the properties of HIV-specific CXCR5-expressing follicular cytotoxic cells and propose strategies for the functional cure of HIV infection by combining cART and CXCR5 ${ }^{+} \mathrm{CD} 8 \mathrm{~T}$ cells.

\section{IMMUNE EXHAUSTION OF VIRUS- SPECIFIC CD8 T CELLS DURING CHRONIC HIV INFECTION}

In response to an acute viral infection, virus-specific CD8 T cells recognize viral peptide-MHC class I complexes presented on the surface of antigen-presenting cells and subsequently become activated by signals transduced from TCR complexes and costimulatory receptors (55-57). The activated CD8 T cells in turn undergo dramatic proliferation and differentiate into effector CD8 T cells that are capable of efficiently clearing virally infected target cells by secreting anti-viral cytokines, such as TNF- $\alpha$ and INF- $\gamma$, as well as cytotoxic molecules, including perforin and granzymes. In the case of mouse lymphocytic choromeningitis virus (LCMV)-Armstrong and human influenza infection, and in response to smallpox and yellow fever vaccines, a large number of effector CD8 T cells with potent anti-viral functions eventually eradicate infectious viral particles within 8-10 days (58-60). Consistent with the resolution of viral infection and inflammation, the majority ( $>90 \%$ ) of virus-specific effector CD8 T cells die of apoptosis, while a small fraction of these effector cells will survive and progressively differentiate into memory CD8 T cells (61-63). Memory CD8 T cells possess a stem cell-like property, being able to maintain themselves long-term through antigenindependent self-renewal driven by the cytokines interleukin-7 and IL-15 (59, 64). Most importantly, quiescent memory CD8 $\mathrm{T}$ cells largely preserve the epigenetic modification features of genes associated with effector functions that are developed at the effector stage, allowing these cells to rapidly exert multiple effector functions and efficiently clear invaded viruses soon after re-infections occur (65-67).

In contrast to acute viral infection, the continuous stimulation by persistent viral antigens due to unresolved chronic viral infection leads to a distinct differentiated state of activated virus-specific CD8 T cells termed immune exhaustion (68-71). Distinct from memory CD8 T cells, exhausted CD8 T cells exhibit several unique features, including, but not limited to, reduced cell proliferation potential upon re-stimulation, enhanced turnover rate due to being more prone to apoptosis, programmed and hierarchal loss of the ability to secrete cytokines and release cytotoxic granule components, prolonged and enhanced expression of an array of inhibitory receptors, altered epigenetic and metabolic signatures, and a failure to further convert to traditional memory CD8 T cells (72-76). The exhaustion of CD8 $\mathrm{T}$ cells was first discovered in a mouse model of chronic infection with LCMV and later on confirmed in various chronic viral infections in human, such as HIV and the hepatitis $\mathrm{C}$ and $\mathrm{B}$ viruses $(21,68,77-80)$.

Similar to chronic LCMV infection in mice, chronic HIV infection does not clonally delete HIV-specific $\mathrm{CD}^{+} \mathrm{T}$ cells; instead, these cells also undergo a progressive and hierarchical loss of effector functions and display enhanced expression of a set of inhibitory receptors, such as programmed cell death-1 (PD-1), cytotoxic T-lymphocyte-associated protein 4 (CTLA-4), lymphocyte activation gene 3 , and $\mathrm{T}$ cell immunoglobulin domain and mucin domain 3 (Tim-3), and a failure to differentiate into classical memory CD8 T cells evidenced by elevated apoptosis, diminished proliferation potential, and a rapid loss of CD127 expression (81-90). Moreover, at the genome-wide transcriptome level, similarities have been observed between exhausted LCMVspecific CD8 T cells and HIV-specific CD8 T cells $(88,91)$. The antigen load appears to be a critical cause that drives the development of these shared transcriptional signatures associated with CD8 T cell exhaustion in both chronic LCMV and HIV infection $(23,69,92)$. The durable exposure to persistent antigen stimulation profoundly impacts the intrinsic epigenetic program and alters the expression mode of key transcriptional factors, such as T-bet, Eomes, TCF-1, Batf, and Id2-E2A, in exhausted LCMV- and HIV-specific CD8 T cells $(23,45,72,91,93)$. The co-expression of inhibitory molecules, such as PD-1, CTLA4, and Tim-3, further promotes the extent of CD8 T cell exhaustion $(22,94-96)$. Additionally, the lack of optimal CD4 T cell help, at least partially mediated by IL- 21 secreted from this population, represents another important factor for CD8 $\mathrm{T}$ cell exhaustion in both chronic LCMV and HIV infection (97-102). Furthermore, regulatory $\mathrm{T}$ cells (Tregs) and myeloid-derived suppressor cells (MDSCs) may further corroborate the progress of CD8 T cell exhaustion (103-107). The general similar characteristics between exhausted LCMV- and HIV-specific CD8 T cells highlight the great value of murine LCMV chronic infection as an informative experimental system to explore and reveal novel aspects of CD8 T-cell immunity in chronic HIV infection, even though murine LCMV infection is not an ideal model for HIV virology.

Although exhausted CD8 T cells are unable to differentiate into classical memory $\mathrm{T}$ cells, they are also not all terminally differentiated cells, which is supported by the consequences of the partial rescue of proliferative potential and effector function of exhausted CD8 T cells by targeting the PD-L1/PD-1 inhibitory pathway with an antibody blockade both in vivo (mouse chronic LCMV infection and rhesus macaque chronic SIV infection) 
and in vitro (co-culturing PD-L1 blockade antibodies with HIVspecific exhausted CD8 T cells) (108-110).

Furthermore, at the population level, exhausted CD8 T cells are not functionally inert and still maintain the critical ability to suppress viral replication during chronic LCMV and HIV infection $(16-19,111)$. The non-terminal differentiation state and partially preserved effector function of exhausted CD8 T cells provide precious opportunities for therapeutically targeting and reinvigorating exhausted CD8 T cells, which can possibly lead to the efficient control of chronic viral infection.

\section{DIFFERENTIATION OF THE FOLLICULAR CXCR5-EXPRESSING CD8 T-CELL SUBSET DURING HIV INFECTION}

Although exhausted, virus-specific CD8 T cells preserve a certain ability to mediate an imperative suppression of viral replication in both chronic LCMV and HIV infection (3, 112-114). Given that the majority of virus-specific CD8 T cells are functionally exhausted, it is of great interest to investigate whether the exhausted $\mathrm{CD}^{+} \mathrm{T}$ cell pool contains a specific subset that are responsible for effectively keeping viral replication in check during chronic viral infection. Our recent study has found that during mouse chronic infection with the LCMV-Cl13 strain, but not acute infection with the LCMV-Armstrong strain, a unique subset of exhausted CD8 T cells expressing the chemokine receptor CXCR5 was differentiated (45). These virus-specific CXCR5 ${ }^{+} \mathrm{CD} 8 \mathrm{~T}$ cells possess the ability to migrate into B-cell follicles. Furthermore, CXCR5 ${ }^{+} \mathrm{CD} 8 \mathrm{~T}$ cells express lower levels of inhibitory receptors, such as PD-1, 2B4, and Tim-3, than their CXCR5 ${ }^{-}$counterparts, and accordingly, these cells demonstrate more potent cytotoxicity than the CXCR5 ${ }^{-}$subset. The Id2/E2A axis was found to play an important role in the generation of this subset. Specifically, E2A promotes the generation of this population while Id 2 antagonizes this effect. In patients with chronic HIV infection, a virus-specific CXCR5 ${ }^{+} \mathrm{CD} 8 \mathrm{~T}$ cell subset was also identified in blood and lymph nodes, and the number of $\mathrm{HIV}$-specific CXCR5 ${ }^{+} \mathrm{CD} 8 \mathrm{~T}$ cells inversely correlated with the viral load in blood. Similar to the scenario in chronic LCMV infection, HIV-specific CXCR $5^{+} \mathrm{CD} 8$ T cells also show up in the follicular zone (45). Furthermore, HIVspecific $C X C R 5^{+}$CD 8 T cells exhibit a reduction in Id 2 expression compared to HIV-specific CXCR5-CD8 T cells. These similar characteristics of CXCR $5^{+} \mathrm{CD} 8 \mathrm{~T}$ cells during both chronic LCMV and HIV infection indicate that the differentiation of this unique subset might represent a common mechanism for defense against chronic viral infection.

Several other groups have also reported CXCR $5^{+} \mathrm{CD} 8 \mathrm{~T}$ cell populations during chronic LCMV infection, SIV and HIV infection. In chronic SIV and HIV infection, these reports uniformly demonstrated the follicular localization of CXCR5 ${ }^{+} \mathrm{CD} 8 \mathrm{~T}$ cells in lymphoid tissues $(46,47,49,53,115,116)$. The follicular location may depend on CXCR5 expression (117). However, in LCMV-Cl13 infection in mice, Im et al. found that the majority of these cells were localized in the T-cell zone (52), while we reported that these cells preferentially localized to the B-cell zone (45). This divergence remains an important issue to be further clarified and a possible explanation may be that Im et al. used antibody recognizing TCF- 1 to stain CXCR $5{ }^{+} \mathrm{CD} 8 \mathrm{~T}$ cells. As TCF- 1 is also highly expressed in $\mathrm{T}$-cell zone residing naïve and memory $\mathrm{T}$ cells $(118,119)$, which may potentially cause false positive. Intra-vital multi-photon confocal microscopy represents a reliable tool to visualize the dynamics of follicular-residing lymphocytes in a real-time pattern, which may provide more solid evidence as to the exact locations of virus-specific CXCR $5^{+} \mathrm{CD} 8 \mathrm{~T}$ cells in lymphoid tissues during chronic viral infection. Furthermore, both studies found that $\mathrm{CXCR} 5^{+} \mathrm{CD} 8 \mathrm{~T}$ cells preserved a better proliferative potential than $\mathrm{CXCR}^{-} \mathrm{CD} 8 \mathrm{~T}$ cells $(45,52)$. We also defined the continuous conversion of $\mathrm{CXCR}^{+} \mathrm{CD} 8 \mathrm{~T}$ cells into CXCR5 ${ }^{-} \mathrm{CD} 8$ T cells during LCMV chronic infection in mice, which was likely driven by elevated Id 2 expression in $\mathrm{CXCR}^{+} \mathrm{CD} 8 \mathrm{~T}$ cells (45). The replenishment of this population critically depends on new emigrants from the thymus (45). It is worthwhile to investigate whether these features also hold true in chronic SIV and HIV infection, which can be determined by using non-human primate models and a bone marrow-liver-thymus humanized mouse model, respectively.

It should be noted that in chronic LCMV-Cl13 infection in mice, viruses seldom infect cells residing in B-cell follicles, while in chronic SIV and HIV infection, viruses predominantly and productively infect follicle-residing TFH cells (25, 120-122). Therefore, in LCMV-Cl13 infection, the antigen loads and inhibitory microenvironment in $\mathrm{B}$-cell follicles are relatively friendly toward virus-specific CXCR5 ${ }^{+} \mathrm{CD} 8 \mathrm{~T}$ cells, and $\mathrm{B}$-cell follicles may function as a sanctuary for virus-specific CXCR $5^{+} \mathrm{CD} 8$ $\mathrm{T}$ cells to prevent the rapid loss of their number and effector functions. In contrast, in chronic SIV and HIV infection, viral replication is more concentrated in TFH cells in B-cell follicles $(29,120,123)$. Therefore, the high antigen loads in B-cell follicles may drive the more severe exhaustion of follicle-residing HIV-specific CXCR5 ${ }^{+} \mathrm{CD} 8 \mathrm{~T}$ cells. The enhanced strength and duration of TCR stimulation from high antigen loads cause the rapid loss of these exhausted cells by apoptosis, which may partially explain the scarcity of this subset in B-cell follicles in chronic SIV and HIV infection. PD-1 is a central mediator that negatively regulates the exhaustion of virus-specific CD8 $\mathrm{T}$ cells $(81,124)$. In chronic LCMV infection, virus-specific CXCR $5^{+} \mathrm{CD} 8 \mathrm{~T}$ cells were found to express relatively lower PD-1 levels compared to virus-specific CXCR5-CD8 $\mathrm{T}$ cells (45). In contrast, during chronic HIV infection, HIV-specific CXCR5 ${ }^{+} \mathrm{CD} 8 \mathrm{~T}$ cells expressed higher levels of PD-1 than their CXCR5 ${ }^{-}$counterparts (47). This divergence in PD- 1 expression in virus-specific $\mathrm{CXCR}^{+} \mathrm{CD} 8 \mathrm{~T}$ cells during chronic LCMV and HIV infection might be largely attributed to the different antigen load levels in B-cell follicles during chronic LCMV and HIV infection (Figure 1) (Table 1).

\section{THE FUNCTIONALITY OF FOLLICULAR CXCR5-EXPRESSING CD8 T-CELL SUBSET DURING HIV INFECTION}

In LCMV-Cl13 infection, compared to CXCR5-CD8 T cells, virusspecific CXCR5 $^{+} \mathrm{CD} 8 \mathrm{~T}$ cells exhibit elevated effector cytokine 


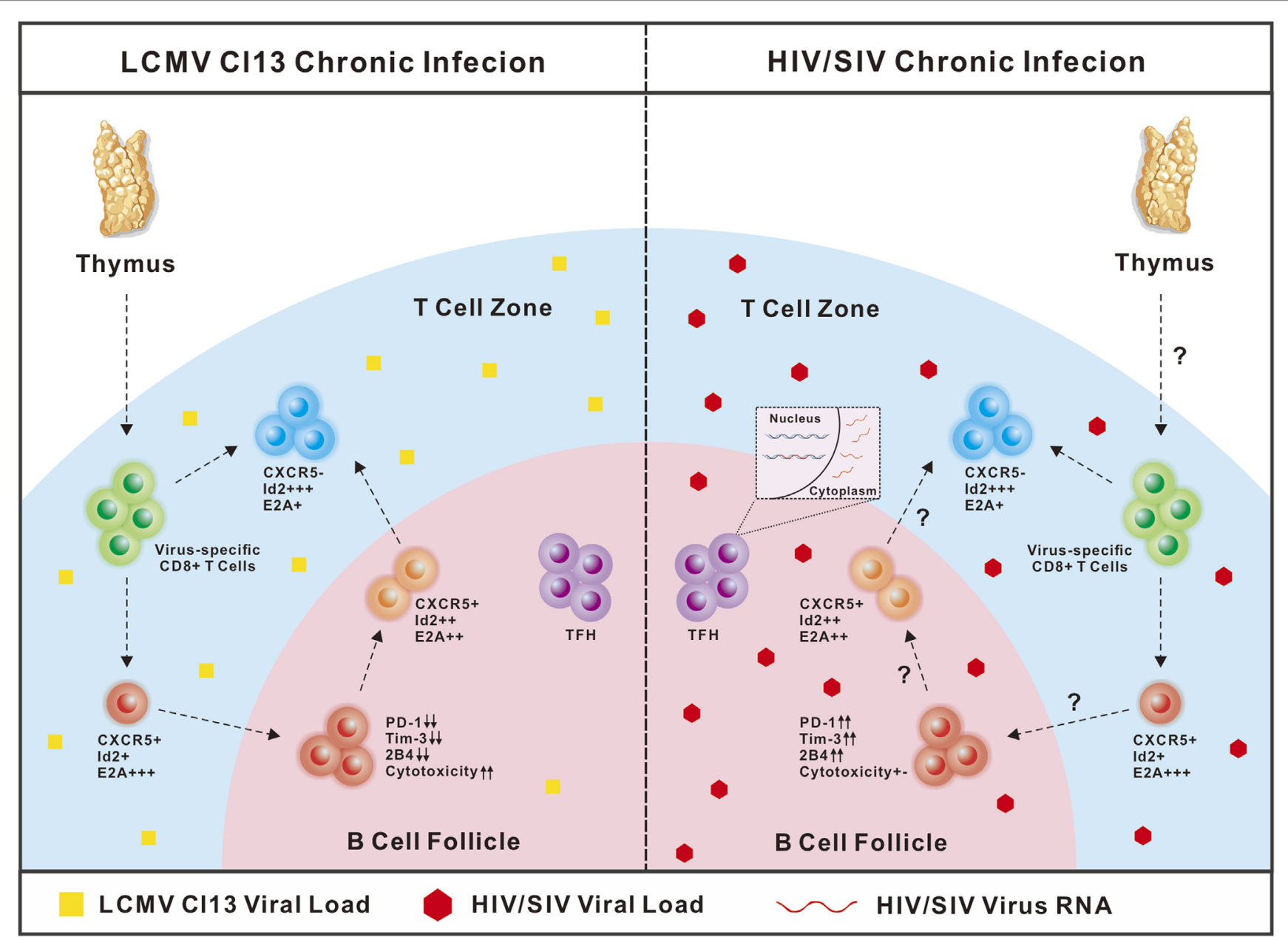

FIGURE 1 | Comparison of CXCR5+CD8 T cells in lymphocytic choromeningitis virus (LCMV)-Cl13 and human immunodeficiency virus (HIV) infection. In chronic LCMV-Cl13 infection, viruses seldom infect B-cell follicles, thus B-cell follicles function as a sanctuary for CXCR5 ${ }^{+}$CD8 T cells to prevent rapid exhaustion. In contrast, HIV virus preferentially targets TFH cells in B-cell follicles for productive and latent infection, thus accumulating high antigen loads in B-cell follicles may drive more severe exhaustion of $\mathrm{CXCR5}{ }^{+} \mathrm{CD} 8 \mathrm{~T}$ cells.

TABLE 1 | The similarities and differences of CXCR5 ${ }^{+}$CD8 T cells in lymphocytic choromeningitis virus (LCMV)-Cl13 and human immunodeficiency virus (HIV)/simian immunodeficiency virus (SIV) infection.

\begin{tabular}{|c|c|c|}
\hline Similarities & $\begin{array}{l}\text { - The number is inversely correlated with viral load in blood } \\
\text { - The subset was identified in blood and lymphoid organs } \\
\text { - Preserve a better proliferative potential than CXCR5-CD8 T cells } \\
\text { - Transcription factor feature: Id2 } \downarrow \text {, E2A } \uparrow \\
\text { - Possess the ability to migrate into B cell follicles }\end{array}$ & \\
\hline & Lymphocytic choromeningitis virus & SIV/HIV \\
\hline \multirow[t]{2}{*}{ Differences } & $\begin{array}{l}\text { Viruses seldom infect cells residing in B-cell follicles, providing a friendly } \\
\text { microenvironment (low antigen load) for CXCR5 } 5^{+} \text {CD8 T cells }\end{array}$ & $\begin{array}{l}\text { Viruses predominantly infect follicle-residing TFH cells leading to a } \\
\text { nasty microenvironment (high antigen load) for CXCR5 }{ }^{+} \text {CD8 } T \text { cells }\end{array}$ \\
\hline & $\begin{array}{l}\text { More potent cytotoxicity than CXCR5- counterparts (e.g. IFN- } \gamma \text {, TNF- } \alpha \text {, and } \\
\text { degranulation) }\end{array}$ & $\begin{array}{l}\text { Controversial issue: enhanced or comparable effector functions } \\
\text { relative to CXCR5-CD8 T cells? }\end{array}$ \\
\hline
\end{tabular}

expression, including IFN- $\gamma$ and TNF- $\alpha$, in response to antigen stimulation. They also display enhanced degranulation. Consistent with these characteristics, these cells are more efficient at killing target cells in vivo than the CXCR5 ${ }^{-}$counterparts. Furthermore, when adoptively transferred to CD8-deficient recipients chronically infected with $\mathrm{LCMV}-\mathrm{Cl} 13$, virus-specific CXCR5 ${ }^{+} \mathrm{CD} 8$ $\mathrm{T}$ cells, but not CXCR5 ${ }^{-} \mathrm{CD} 8 \mathrm{~T}$ cells, can effectively inhibit viral replication in recipients (45). Together, these results demonstrate 
that virus-specific $\mathrm{CXCR} 5^{+} \mathrm{CD} 8 \mathrm{~T}$ cells preserve better effector functions than CXCR5 ${ }^{-} \mathrm{CD} 8 \mathrm{~T}$ cells in suppressing chronic viral infection. However, there are conflicting results regarding the functionality of $\mathrm{CXCR}^{+} \mathrm{CD} 8 \mathrm{~T}$ cells in chronic HIV infection. Several reports have shown that compared to CXCR5 ${ }^{-} \mathrm{CD} 8$ $\mathrm{T}$ cells, CXCR5 ${ }^{+} \mathrm{CD} 8 \mathrm{~T}$ cells show an increase in the production of IFN- $\gamma$, TNF- $\alpha$, and perforin; enhanced degranulation and cytolytic activities $(45,46,53,115)$. In contrast, a recent study demonstrated the comparable production of cytolytic proteins between $\mathrm{HIV}$-specific $\mathrm{CXCR} 5^{+} \mathrm{CD} 8 \mathrm{~T}$ cells and CXCR5 ${ }^{-} \mathrm{CD} 8$ $\mathrm{T}$ cells in lymphoid tissues from patients with chronic infection, but much lower than that of HIV-specific CD8 T cells in blood (50). It should be noted that HIV-specific CXCR5 ${ }^{+} \mathrm{CD} 8 \mathrm{~T}$ cells are still exhausted cells. Similar to LCMV-specific CXCR $5^{+}$CD 8 $\mathrm{T}$ cells, these cells are most likely heterogeneous, consisting of newly recruited cells (less exhausted due to the short exposure time to antigens) from thymic outputs and past generated cells (more exhausted due to the concentrated viral replication in B-cell follicles). Whole body viral loads and disease progression might potentially influence the ratio between newly and past generated HIV-specific CXCR5 ${ }^{+} \mathrm{CD} 8 \mathrm{~T}$ cells. Interestingly, Miles et al. reported that the majority of follicular CD8 $\mathrm{T}$ cells are regulatory CD8 T cells with the expression of CD44 and CXCR5. This regulatory subset expresses less perforin and high level of Tim-3 to inhibit IL-21 production by TFH cells and impairs GC function in SIV and ex vivo HIV infection (49). However, whether these regulatory CD8 T cells are SIV- or HIV-specific awaits further investigation. Furthermore, we may not rule out the possibility that certain subset of antigen-specific CD8 T cells become de novo CXCR5-expressing cells and be included in the analysis in responding to antigen stimulation. Furthermore, the more exhausted state of $\mathrm{CXCR} 5^{+} \mathrm{CD} 8 \mathrm{~T}$ cells from more concentrated viral antigens in B-cell follicles may also explain their lower cytolytic activities when compared to total HIV-specific CD8 T cells in blood. Next, it is interesting to directly compare the functional capacity of $\mathrm{HIV}$-specific CXCR $5{ }^{+} \mathrm{CD} 8 \mathrm{~T}$ cells from lymphoid tissues and blood (50).

Although there are conflicting results regarding the expression of inhibitory molecules and their functional capacities, it is a consensus that the number of HIV- or SIV-specific CXCR $5{ }^{+} \mathrm{CD} 8 \mathrm{~T}$ cells inversely correlates with plasma viremia and disease progression $(31,45,48,54,116)$, highlighting a critical functional role of this subset in viral control during chronic SIV or HIV infection. Given the possible downregulated effector functions and cytolytic activities, this important characteristic of $\mathrm{CXCR}^{+} \mathrm{CD} 8 \mathrm{~T}$ cells might be largely attributed to their non-terminal differentiation state and better-retained proliferative potential. Indeed, HIV-specific CXCR5 ${ }^{+} \mathrm{CD} 8 \mathrm{~T}$ cells express less Id 2 (promoting terminal differentiation) and higher TCF-1 (promoting memory differentiation and proliferative potential) than CXCR5 ${ }^{-}$CD8 $\mathrm{T}$ cells $(45,47,51,125)$. In a chronic LCMV-Cl13 infection model, overexpressing Id 2 or ablating TCF-1 leads to the impaired generation of virus-specific CXCR5 ${ }^{+} \mathrm{CD} 8 \mathrm{~T}$ cells and accordingly to increased viral loads $(45,47,52)$. Moreover, virus-specific CXCR $5^{+} \mathrm{CD} 8 \mathrm{~T}$ cells, but not CXCR5 ${ }^{-} \mathrm{CD} 8 \mathrm{~T}$ cells, respond to the PD-1-PD-L1 pathway blockade and increase clonal expansion $(45,52)$. In chronic HIV infection, memory-like HIV-specific CXCR5 ${ }^{+} \mathrm{CD} 8 \mathrm{~T}$ cells may persist longer than their $\mathrm{CXCR}^{-}$counterparts at population levels and continuously kill virus-infected cells. By contrast, because B-cell follicle-residing TFH cells are major virus producers compared to other CD4 T cell types in the T cell zone in HIV infection $(24,120)$, it is reasonable to infer that HIV-specific CXCR5 ${ }^{+} \mathrm{CD} 8 \mathrm{~T}$ cells, but not $\mathrm{CXCR}^{-} \mathrm{CD} 8 \mathrm{~T}$ cells, have chances to come into contact with and kill these target cells. Therefore, HIV-specific CXCR5 ${ }^{+}$CD 8 $\mathrm{T}$ cells primarily rely on their memory-like properties and unique anatomical location for their critical control of viral replication in the context of chronic HIV infection.

\section{STRATEGIES FOR EMPLOYING CXCR5+CD8 T CELLS TO PURGE HIV RESERVOIRS IN B-CELL FOLLICLES}

It has been well-documented that virus-specific CD8 T cells are required for the elimination of $\operatorname{HIV}$ reservoirs $(3,112,126)$. Accumulating evidence has demonstrated that TFH cells in B-cell follicles of lymphoid tissue serve a major HIV reservoir, as viruses preferentially target TFH populations for productive and latent infection $(25,26)$. Taking into account that a limited number and exhausted state of HIV- or SIV-specific CXCR5 ${ }^{+} \mathrm{CD} 8 \mathrm{~T}$ cells were present in B-cell follicles, this unique strategy largely protects these viruses from the attacks mediated by virus-specific CD8 $\mathrm{T}$ cells. Indeed, in elite controllers from chronic SIV infection, SIV-specific CD8 T cells can effectively control viral replication at extra-follicular sites; however, the majority of these cells fail to migrate to B-cell follicles to clear SIV-producing TFH cells $(19,30,31)$. In ART-treated, aviremic non-human primates and patients, lymph node $\mathrm{PD}-1^{+} \mathrm{TFH}$ populations also serve as a major reservoir for active and persistent viral transcription (28). Thus, HIV reservoirs harbored in TFH cell populations in lymph node B-cell follicles represent a major obstacle for a functional cure for HIV infection. To this end, the appearance of a large number of HIV-specific CXCR $5^{+} \mathrm{CD} 8 \mathrm{~T}$ cells equipped with potent cytotoxic functions is a prerequisite for effectively eliminating TFH reservoirs under cART treatment. Additionally, CXCR $5^{+} \mathrm{CD} 8 \mathrm{~T}$ cells are not stable and will eventually convert into CXCR5-CD8 T cells, which will exit B-cell follicles (45). Therefore, we speculate that the rational design of strategies for a functional cure for HIV infection will rely on the following three important aspects: (1) enhanced virus-specific CXCR5 ${ }^{+}$CD8 T cell differentiation, (2) preserved lineage stability, and (3) functional reinvigoration.

In chronic LCMV-Cl13 infection, we have shown a greater therapeutic potential for LCMV-specific CXCR5 ${ }^{+} \mathrm{CD} 8 \mathrm{~T}$ cells than the CXCR5 ${ }^{-}$subset upon adoptive transfer to chronically infected mice, as well as synergistic effects that reduce the viral load when combined with anti-PD-L1 treatment (45). In an SIV model or HIV patients, it is also worth testing the efficacy of this combination for suppressing HIV replication and latency in TFH cells in non-human primates or patients under ART treatment. Virus-specific CXCR5 ${ }^{+}$CD 8 T cells, but not CXCR5 ${ }^{-}$CD8 T cells, are PD-1 pathway blockade responders (52). In this regard, PD-1 blockade antibodies can effectively expand transferred virusspecific CXCR5 ${ }^{+}$CD8 $\mathrm{T}$ cells and boost the effector functions 
of these cells. Velu et al. demonstrated that during chronic SIV infection, PD-1 blockade resulted in rapid expansion of virus-specific CD8 T cells with improved functionality (127). However, the reduction of plasma viral load seemed not to be that impressive, which may be due to a very limited number of $\mathrm{CXCR}^{+}{ }^{+} \mathrm{CD} 8^{+} \mathrm{T}$ cells in situ. Therefore, the combination of PD-1 blockade with adoptive transfer of large number of virusspecific CXCR5 ${ }^{+} \mathrm{CD} 8 \mathrm{~T}$ cells may further improve the control of viral replication. Furthermore, the PD-1 pathway blockade may also have partial effects on TFH cells, which express a high abundance of PD-1. The activation of TFH cells latently infected with viruses by the PD-1 antibody blockade may enhance the transcription of viral genes, which may increase antigenic exposure for cytotoxic killing due to the transfer of virus-specific CXCR $5^{+} \mathrm{CD} 8 \mathrm{~T}$ cells. In addition to the adoptive transfer of in vitro expanded endogenous $\mathrm{CXCR} 5^{+} \mathrm{CD} 8 \mathrm{~T}$ cells from blood, it is also possible to transfer genetically modified virus-specific CD8 $\mathrm{T}$ cells over-expressing transcriptional factors that promote the differentiation and lineage stabilization of CXCR $5^{+} \mathrm{CD} 8 \mathrm{~T}$ cells, such as E2A and Bcl-6 (Figure 2). Besides, adoptive transfer of antiviral chimeric antigen receptor (CAR) $\mathrm{T}$ cells co-expressing the follicular homing chemokine receptor CXCR5 could potently suppress SIV replication in vivo (128). In addition to adoptive transfer, therapeutic vaccination plus the $\mathrm{PD}-1$ pathway blockade may also boost the differentiation and functional rescue of virus-specific CXCR5 ${ }^{+}$CD 8 T cells $(129,130)$. Furthermore, a recent study has demonstrated that a novel IL-15 agonist ALT803 could activate and direct SIV-specific CD8 T cells into B cell follicles via upregulation of CXCR5 (131). Thus, the combination of IL-15 agonist and strategies mentioned above may offer a new immunotherapeutic agent for purging HIV reservoirs in B-cell follicles.

\section{A Enhanced CXCR5+CD8+T cell number}

HIV patient

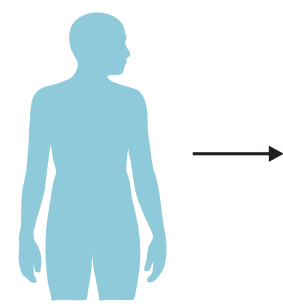

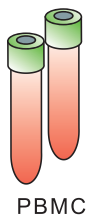

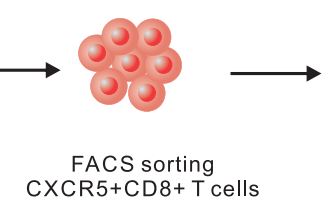

CXCR5+CD8+T cells
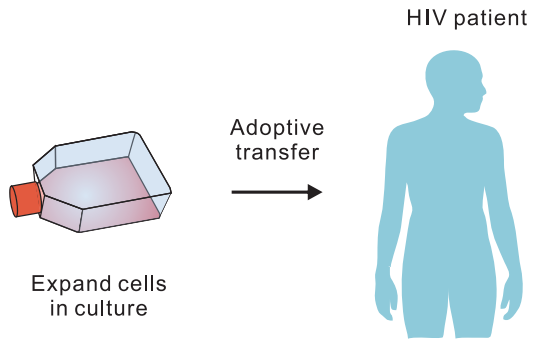

\section{B Preserved CXCR5+CD8+ T cell lineage stability}

HIV patient
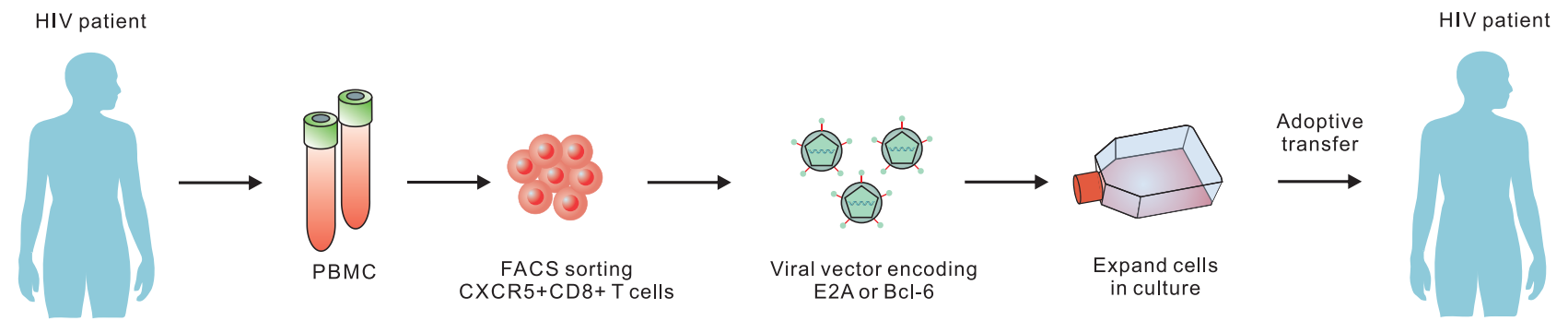

FACS sorting CXCR5+CD $8+T$ cells

Viral vector encoding

$\mathrm{E} 2 \mathrm{~A}$ or $\mathrm{Bcl}-6$

\section{Functional reinvigoration}

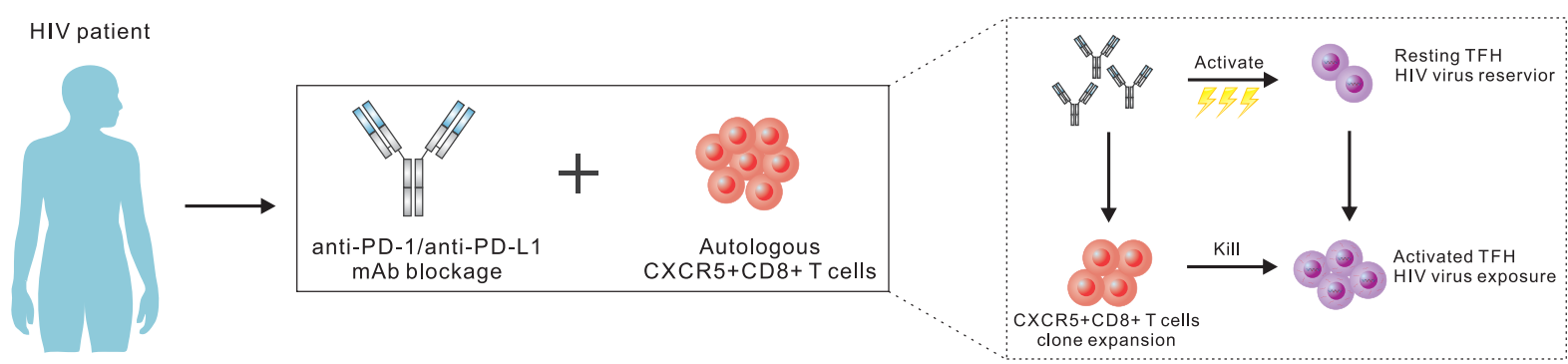

FIGURE 2 | Potential strategies for employing CXCR5+CD8 T cells to purge human immunodeficiency virus (HIV) reservoirs in B cell follicles. (A) Adoptive transfer of in vitro expanded endogenous CXCR5 ${ }^{+} \mathrm{CD} 8 \mathrm{~T}$ cells from blood. As CXCR5+CD8 T cells from peripheral blood will further differentiate into CXCR5-CD8 T cells upon antigen re-stimulation, the development of in vitro culturing conditions optimal for both expanding and preserving the migratory and functional characteristics of CXCR5 ${ }^{+}$CD8 $T$ cells should be a focus for future investigations. (B) Transfer genetically modified virus-specific CD8 T cells over-expressing transcriptional factors that promote the differentiation and lineage stabilization of CXCR5 ${ }^{+} \mathrm{CD} 8 \mathrm{~T}$ cells. (C) Programmed cell death-1 pathway blockade may effectively expand transferred virus-specific CXCR5+CD8 T cells and boost the effector functions. 


\section{CONCLUSION}

Based on the phenotypic, anatomic, and functional characterization of virus-specific CXCR $5^{+} \mathrm{CD} 8 \mathrm{~T}$ cells in chronic viral infection, this subset has drawn immense attention and many new findings have been learned allowing us to better understand its features. Published data have firmly established the notion that this population is localized in B-cell follicles and plays a critical role in repressing viral load during chronic HIV infection. However, many important questions remain unanswered regarding the basic biology of this unique subset. For example, little is known regarding the origin and early fate commitment of this subset. Additionally, we barely know the cytokine milieu that is involved in the differentiation of this subset. Understand the characteristics of these cells will facilitate the optimization of in vitro culture conditions for the efficient expansion of these cells for therapeutic purposes.

It is also important to investigate whether and how these cells kill TFH cells that are actively transcribing viral RNAs in $\mathrm{B}$-cell follicles during HIV infection. It is also of great interest to examine whether this population is required for the elimination of latently infected TFH cells after "shock and kill" intervention. Furthermore, we need to develop various immune strategies,

\section{REFERENCES}

1. Gandhi RT, Walker BD. Immunologic control of HIV-1. Annu Rev Med (2002) 53:149-72. doi:10.1146/annurev.med.53.082901.104011

2. Piazza P, Fan Z, Rinaldo CR Jr. CD8+ T-cell immunity to HIV infection. Clin Lab Med (2002) 22(3):773-97. doi:10.1016/S0272-2712(02)00006-9

3. Jones RB, Walker BD. HIV-specific CD8(+) T cells and HIV eradication. J Clin Invest (2016) 126(2):455-63. doi:10.1172/JCI80566

4. Walker CM, Moody DJ, Stites DP, Levy JA. CD8+ lymphocytes can control HIV infection in vitro by suppressing virus replication. Science (1986) 234(4783):1563-6. doi:10.1126/science.2431484

5. Tsubota H, Lord CI, Watkins DI, Morimoto C, Letvin NL. A cytotoxic T lymphocyte inhibits acquired immunodeficiency syndrome virus replication in peripheral blood lymphocytes. J Exp Med (1989) 169(4):1421-34. doi:10.1084/jem.169.4.1421

6. Borrow P, Lewicki H, Hahn BH, Shaw GM, Oldstone MB. Virus-specific CD8+ cytotoxic T-lymphocyte activity associated with control of viremia in primary human immunodeficiency virus type 1 infection. J Virol(1994) 68(9): 6103-10.

7. Freel SA, Picking RA, Ferrari G, Ding H, Ochsenbauer C, Kappes JC, et al. Initial HIV-1 antigen-specific CD8+ T cells in acute HIV-1 infection inhibit transmitted/founder virus replication. J Virol (2012) 86(12):6835-46. doi:10.1128/JVI.00437-12

8. Koup RA, Safrit JT, Cao Y, Andrews CA, McLeod G, Borkowsky W, et al. Temporal association of cellular immune responses with the initial control of viremia in primary human immunodeficiency virus type 1 syndrome. J Virol (1994) 68(7):4650-5.

9. Ndhlovu ZM, Kamya P, Mewalal N, Kloverpris HN, Nkosi T, Pretorius K, et al. Magnitude and kinetics of CD8+ T cell activation during hyperacute HIV infection impact viral set point. Immunity (2015) 43(3):591-604. doi:10.1016/j.immuni.2015.08.012

10. Klein MR, van Baalen CA, Holwerda AM, Kerkhof Garde SR, Bende RJ, Keet IP, et al. Kinetics of Gag-specific cytotoxic T lymphocyte responses during the clinical course of HIV-1 infection: a longitudinal analysis of rapid progressors and long-term asymptomatics. J Exp Med (1995) 181(4):1365-72. doi:10.1084/jem.181.4.1365

11. Migueles SA, Sabbaghian MS, Shupert WL, Bettinotti MP, Marincola FM, Martino L, et al. HLA $B^{\star} 5701$ is highly associated with restriction of virus replication in a subgroup of $\mathrm{HIV}$-infected long term nonprogressors. Proc Natl Acad Sci U S A (2000) 97(6):2709-14. doi:10.1073/pnas.050567397 such as vaccination, that can be utilized to efficiently induce and stabilize this population. Provided that the major reservoir is harbored in B-cell follicle TFH cells, and CXCR $5^{+} \mathrm{CD} 8 \mathrm{~T}$ cells are the sole virus-specific population that has the chance and ability to gain access to these reservoirs, understanding the molecular mechanisms underlying the differentiation, migration, and function of this unique subset will definitely provide important insights that will allow us to harness this population for a functional cure against HIV infection.

\section{AUTHOR CONTRIBUTIONS}

MX, RH, and LY wrote and edited the manuscript. XC designed the figures.

\section{ACKNOWLEDGMENTS}

We thank all the lab members from LY's lab for discussing this manuscript. This study was supported by grants from the National Key Research Development Plan of China (No.2016YFA0502202 to LY) and the National Natural Science Foundation of China (No. 81471624 to LY).

12. Bansal A, Yue L, Conway J, Yusim K, Tang J, Kappes J, et al. Immunologica control of chronic HIV-1 infection: HLA-mediated immune function and viral evolution in adolescents. AIDS (2007) 21(18):2387-97. doi:10.1097/ QAD.0b013e3282f13823

13. Tang J, Wilson CM, Meleth S, Myracle A, Lobashevsky E, Mulligan MJ, et al. Host genetic profiles predict virological and immunological control of HIV-1 infection in adolescents. AIDS (2002) 16(17):2275-84. doi:10.1097/ 00002030-200211220-00007

14. Loffredo JT, Sidney J, Bean AT, Beal DR, Bardet W, Wahl A, et al. Two MHC class I molecules associated with elite control of immunodeficiency virus replication, Mamu-B ${ }^{\star} 08$ and HLA-B ${ }^{\star} 2705$, bind peptides with sequence similarity. J Immunol (2009) 182(12):7763-75. doi:10.4049/jimmunol.0900111

15. Nomura T, Matano T. Association of MHC-I genotypes with disease progression in HIV/SIV infections. Front Microbiol (2012) 3:234. doi:10.3389/ fmicb.2012.00234

16. Price DA, West SM, Betts MR, Ruff LE, Brenchley JM, Ambrozak DR, et al. T cell receptor recognition motifs govern immune escape patterns in acute SIV infection. Immunity (2004) 21(6):793-803. doi:10.1016/j.immuni. 2004.10.010

17. Walker B, McMichael A. The T-cell response to HIV. Cold Spring Harb Perspect Med (2012) 2(11):a007054. doi:10.1101/cshperspect.a007054

18. Jin X, Bauer DE, Tuttleton SE, Lewin S, Gettie A, Blanchard J, et al. Dramatic rise in plasma viremia after CD8(+) $\mathrm{T}$ cell depletion in simian immunodeficiency virus-infected macaques. J Exp Med (1999) 189(6):991-8 doi:10.1084/jem.189.6.991

19. Schmitz JE, Kuroda MJ, Santra S, Sasseville VG, Simon MA, Lifton MA, et al. Control of viremia in simian immunodeficiency virus infection by CD8+ lymphocytes. Science (1999) 283(5403):857-60. doi:10.1126/science. 283.5403.857

20. Cartwright EK, Spicer L, Smith SA, Lee D, Fast R, Paganini S, et al. CD8(+) lymphocytes are required for maintaining viral suppression in SIV-infected macaques treated with short-term antiretroviral therapy. Immunity (2016) 45(3):656-68. doi:10.1016/j.immuni.2016.08.018

21. El-Far M, Halwani R, Said E, Trautmann L, Doroudchi M, Janbazian L, et al. T-cell exhaustion in HIV infection. Curr HIV/AIDS Rep (2008) 5(1):13-9. doi:10.1007/s11904-008-0003-7

22. Khaitan A, Unutmaz D. Revisiting immune exhaustion during HIV infection. Curr HIV/AIDS Rep (2011) 8(1):4-11. doi:10.1007/s11904-010-0066-0

23. Youngblood B, Noto A, Porichis F, Akondy RS, Ndhlovu ZM, Austin JW, et al. Cutting edge: prolonged exposure to HIV reinforces a poised epigenetic 
program for PD-1 expression in virus-specific CD8 T cells. J Immunol (2013) 191(2):540-4. doi:10.4049/jimmunol.1203161

24. Kohler SL, Pham MN, Folkvord JM, Arends T, Miller SM, Miles B, et al. Germinal center $\mathrm{T}$ follicular helper cells are highly permissive to HIV-1 and alter their phenotype during virus replication. J Immunol (2016) 196(6):2711-22. doi:10.4049/jimmunol.1502174

25. Hufert FT, van Lunzen J, Janossy G, Bertram S, Schmitz J, Haller O, et al. Germinal centre $\mathrm{CD} 4+\mathrm{T}$ cells are an important site of HIV replication in vivo. AIDS (1997) 11(7):849-57. doi:10.1097/00002030-19970700000003

26. Perreau M, Savoye AL, De Crignis E, Corpataux JM, Cubas R, Haddad EK, et al. Follicular helper $\mathrm{T}$ cells serve as the major CD4 $\mathrm{T}$ cell compartment for HIV-1 infection, replication, and production. J Exp Med (2013) 210(1): 143-56. doi:10.1084/jem.20121932

27. Leong YA, Atnerkar A, Yu D. Human immunodeficiency virus playing hideand-seek: understanding the TFH cell reservoir and proposing strategies to overcome the follicle sanctuary. Front Immunol (2017) 8:622. doi:10.3389/ fimmu.2017.00622

28. Banga R, Procopio FA, Noto A, Pollakis G, Cavassini M, Ohmiti K, et al. PD-1(+) and follicular helper T cells are responsible for persistent HIV-1 transcription in treated aviremic individuals. Nat Med (2016) 22(7):754-61. doi: $10.1038 / \mathrm{nm} .4113$

29. Fukazawa Y, Lum R, Okoye AA, Park H, Matsuda K, Bae JY, et al. B cell follicle sanctuary permits persistent productive simian immunodeficiency virus infection in elite controllers. Nat Med (2015) 21(2):132-9. doi:10.1038/ nm.3781

30. Connick E, Mattila T, Folkvord JM, Schlichtemeier R, Meditz AL, Ray MG, et al. CTL fail to accumulate at sites of HIV-1 replication in lymphoid tissue. J Immunol (2007) 178(11):6975-83. doi:10.4049/jimmunol.178.11.6975

31. Connick E, Folkvord JM, Lind KT, Rakasz EG, Miles B, Wilson NA, et al. Compartmentalization of simian immunodeficiency virus replication within secondary lymphoid tissues of rhesus macaques is linked to disease stage and inversely related to localization of virus-specific CTL. J Immunol (2014) 193(11):5613-25. doi:10.4049/jimmunol.1401161

32. Hong FF, Mellors JW. Impact of antiretroviral therapy on HIV-1 persistence: the case for early initiation. AIDS Rev (2015) 17(2):71-82.

33. Kabbara WK, Ramadan WH. Emtricitabine/rilpivirine/tenofovir disoproxil fumarate for the treatment of HIV-1 infection in adults. J Infect Public Health (2015) 8(5):409-17. doi:10.1016/j.jiph.2015.04.020

34. Pau AK, George JM. Antiretroviral therapy: current drugs. Infect Dis Clin North Am (2014) 28(3):371-402. doi:10.1016/j.idc.2014.06.001

35. Frost SD, Martinez-Picado J, Ruiz L, Clotet B, Brown AJ. Viral dynamics during structured treatment interruptions of chronic human immunodeficiency virus type 1 infection. J Virol (2002) 76(3):968-79. doi:10.1128/JVI. 76.3.968-979.2002

36. Ruiz L, Martinez-Picado J, Romeu J, Paredes R, Zayat MK, Marfil S, et al. Structured treatment interruption in chronically HIV-1 infected patients after long-term viral suppression. AIDS (2000) 14(4):397-403. doi:10.1097/ 00002030-200003100-00013

37. Oxenius A, Price DA, Gunthard HF, Dawson SJ, Fagard C, Perrin L, et al. Stimulation of HIV-specific cellular immunity by structured treatment interruption fails to enhance viral control in chronic HIV infection. Proc Natl Acad Sci U S A (2002) 99(21):13747-52. doi:10.1073/pnas.202372199

38. Brask S, Hager H, Pallesen G, Porwit A, Biberfeld P, Gerstoft J. Quantification of CD8-positive lymphocytes in lymph node follicles from HIV-infected male homosexuals and controls. Acta Pathol Microbiol Immunol Scand A (1987) 95(4):155-7.

39. Bofill M, Gombert W, Borthwick NJ, Akbar AN, McLaughlin JE, Lee CA, et al. Presence of $\mathrm{CD} 3+\mathrm{CD} 8+\mathrm{Bcl}-2$ (low) lymphocytes undergoing apoptosis and activated macrophages in lymph nodes of HIV-1+ patients. Am J Pathol (1995) 146(6):1542-55.

40. Devergne O, Peuchmaur M, Crevon MC, Trapani JA, Maillot MC, Galanaud P, et al. Activation of cytotoxic cells in hyperplastic lymph nodes from HIV-infected patients. AIDS (1991) 5(9):1071-9. doi:10.1097/ 00002030-199109000-00002

41. Piris MA, Rivas C, Morente M, Rubio C, Martin C, Olivia H. Persistent and generalized lymphadenopathy: a lesion of follicular dendritic cells? An immunohistologic and ultrastructural study. Am J Clin Pathol (1987) 87(6):716-24. doi:10.1093/ajcp/87.6.716
42. Reimann KA, Snyder GB, Chalifoux LV, Waite BC, Miller MD, Yamamoto H, et al. An activated CD8+ lymphocyte appears in lymph nodes of rhesus monkeys early after infection with simian immunodeficiency virus. J Clin Invest (1991) 88(4):1113-20. doi:10.1172/JCI115410

43. Tenner-Racz K, Racz P, Thome C, Meyer CG, Anderson PJ, Schlossman SF, et al. Cytotoxic effector cell granules recognized by the monoclonal antibody TIA-1 are present in CD8+ lymphocytes in lymph nodes of human immunodeficiency virus-1-infected patients. Am J Pathol (1993) 142(6):1750-8.

44. Quigley MF, Gonzalez VD, Granath A, Andersson J, Sandberg JK. CXCR5+ CCR7- CD8 T cells are early effector memory cells that infiltrate tonsil B cell follicles. Eur J Immunol (2007) 37(12):3352-62. doi:10.1002/eji.200636746

45. He R, Hou S, Liu C, Zhang A, Bai Q, Han M, et al. Follicular CXCR5expressing CD8(+) T cells curtail chronic viral infection. Nature (2016) 537(7620):412-28. doi:10.1038/nature19317

46. Petrovas C, Ferrando-Martinez S, Gerner MY, Casazza JP, Pegu A, Deleage C, et al. Follicular CD8 T cells accumulate in HIV infection and can kill infected cells in vitro via bispecific antibodies. Sci Transl Med (2017) 9(373):eaag2285. doi:10.1126/scitranslmed.aag2285

47. Leong YA, Chen Y, Ong HS, Wu D, Man K, Deleage C, et al. CXCR5(+) follicular cytotoxic T cells control viral infection in B cell follicles. Nat Immunol (2016) 17(10):1187-96. doi:10.1038/ni.3543

48. Jiao YM, Yang HG, Huang HH, Tu B, Xing SJ, Mao L, et al. Dichotomous roles of programmed cell death 1 on HIV-specific CXCR5(+) and CXCR5(-) CD8(+) T cells during chronic HIV infection. Front Immunol (2017) 8:1786. doi:10.3389/fimmu.2017.01786

49. Miles B, Miller SM, Folkvord JM, Levy DN, Rakasz EG, Skinner PJ, et al. Follicular regulatory CD8 T cells impair the germinal center response in SIV and ex vivo HIV infection. PLoS Pathog (2016) 12(10):e1005924. doi:10.1371/ journal.ppat.1005924

50. Reuter MA, Del Rio Estrada PM, Buggert M, Petrovas C, FerrandoMartinez S, Nguyen S, et al. HIV-specific CD8(+) T cells exhibit reduced and differentially regulated cytolytic activity in lymphoid tissue. Cell Rep (2017) 21(12):3458-70. doi:10.1016/j.celrep.2017.11.075

51. Perdomo-Celis F, Taborda NA, Rugeles MT. Follicular CD8(+) T cells: origin, function and importance during HIV infection. Front Immunol (2017) 8: 1241. doi:10.3389/fimmu.2017.01241

52. Im SJ, Hashimoto M, Gerner MY, Lee J, Kissick HT, Burger MC, et al. Defining CD8+ T cells that provide the proliferative burst after PD-1 therapy. Nature (2016) 537(7620):417-21. doi:10.1038/nature19330

53. Ferrando-Martinez S, Moysi E, Pegu A, Andrews S, Nganou Makamdop K, Ambrozak D, et al. Accumulation of follicular CD8+ T cells in pathogenic SIV infection. J Clin Invest (2018) 128(5):2089-103. doi:10.1172/JCI96207

54. Perdomo-Celis F, Taborda NA, Rugeles MT. Circulating Cxcr5-expressing $\mathrm{Cd} 8+\mathrm{T}$-cells are major producers of $\mathrm{Il}-21$ and associate with limited HIV replication. J Acquir Immune Defic Syndr (2018). doi:10.1097/ QAI.0000000000001700

55. Zehn D, King C, Bevan MJ, Palmer E. TCR signaling requirements for activating T cells and for generating memory. Cell Mol Life Sci (2012) 69(10):1565-75. doi:10.1007/s00018-012-0965-x

56. Badovinac VP, Haring JS, Harty JT. Initial T cell receptor transgenic cell precursor frequency dictates critical aspects of the $\mathrm{CD} 8(+) \mathrm{T}$ cell response to infection. Immunity (2007) 26(6):827-41. doi:10.1016/j.immuni.2007.04.013

57. Zhang N, Bevan MJ. CD8(+) T cells: foot soldiers of the immune system. Immunity (2011) 35(2):161-8. doi:10.1016/j.immuni.2011.07.010

58. Murali-Krishna K, Altman JD, Suresh M, Sourdive DJ, Zajac AJ, Miller JD, et al. Counting antigen-specific CD8 T cells: a reevaluation of bystander activation during viral infection. Immunity (1998) 8(2):177-87. doi:10.1016/ S1074-7613(00)80470-7

59. Harari A, Dutoit V, Cellerai C, Bart PA, Du Pasquier RA, Pantaleo G. Functional signatures of protective antiviral T-cell immunity in human virus infections. Immunol Rev (2006) 211:236-54. doi:10.1111/j.0105-2896.2006. 00395.x

60. Miller JD, van der Most RG, Akondy RS, Glidewell JT, Albott S, Masopust D, et al. Human effector and memory CD8+ T cell responses to smallpox and yellow fever vaccines. Immunity (2008) 28(5):710-22. doi:10.1016/j. immuni.2008.02.020

61. Kaech SM, Cui W. Transcriptional control of effector and memory CD8+ $\mathrm{T}$ cell differentiation. Nat Rev Immunol (2012) 12(11):749-61. doi:10.1038/ nri3307 
62. Arens R, Schoenberger SP. Plasticity in programming of effector and memory CD8 T-cell formation. Immunol Rev (2010) 235(1):190-205. doi:10.1111/j.0105-2896.2010.00899.x

63. Jameson SC, Masopust D. Diversity in T cell memory: an embarrassment of riches. Immunity (2009) 31(6):859-71. doi:10.1016/j.immuni.2009.11.007

64. Masopust D, Schenkel JM. The integration of T cell migration, differentiation and function. Nat Rev Immunol (2013) 13(5):309-20. doi:10.1038/nri3442

65. Youngblood B, Hale JS, Kissick HT, Ahn E, Xu X, Wieland A, et al. Effector CD8 T cells dedifferentiate into long-lived memory cells. Nature (2017) 552(7685):404-9. doi:10.1038/nature25144

66. Akondy RS, Fitch M, Edupuganti S, Yang S, Kissick HT, Li KW, et al. Origin and differentiation of human memory CD8 T cells after vaccination. Nature (2017) 552(7685):362-7. doi:10.1038/nature24633

67. Youngblood B, Hale JS, Ahmed R. Memory CD8 T cell transcriptional plasticity. F1000Prime Rep (2015) 7:38. doi:10.12703/P7-38

68. Zajac AJ, Blattman JN, Murali-Krishna K, Sourdive DJ, Suresh M, Altman JD, et al. Viral immune evasion due to persistence of activated T cells without effector function. J Exp Med (1998) 188(12):2205-13. doi:10.1084/jem.188. 12.2205

69. Mueller SN, Ahmed R. High antigen levels are the cause of T cell exhaustion during chronic viral infection. Proc Natl Acad Sci U S A (2009) 106(21): 8623-8. doi:10.1073/pnas.0809818106

70. Chun TW, Fauci AS. Latent reservoirs of HIV: obstacles to the eradication of virus. Proc Natl Acad Sci U S A (1999) 96(20):10958-61. doi:10.1073/pnas. 96.20 .10958

71. Wherry EJ. T cell exhaustion. Nat Immunol (2011) 12(6):492-9. doi:10.1038/ ni. 2035

72. Wherry EJ, Kurachi M. Molecular and cellular insights into T cell exhaustion. Nat Rev Immunol (2015) 15(8):486-99. doi:10.1038/nri3862

73. Sauce D, Elbim C, Appay V. Monitoring cellular immune markers in HIV infection: from activation to exhaustion. Curr Opin HIV AIDS (2013) 8(2):125-31. doi:10.1097/COH.0b013e32835d08a9

74. Kalia V, Sarkar S, Ahmed R. CD8 T-cell memory differentiation during acute and chronic viral infections. Adv Exp Med Biol (2010) 684:79-95. doi:10.1007/978-1-4419-6451-9_7

75. Schietinger A, Greenberg PD. Tolerance and exhaustion: defining mechanisms of T cell dysfunction. Trends Immunol (2014) 35(2):51-60. doi:10.1016/j.it.2013.10.001

76. Kahan SM, Wherry EJ, Zajac AJ. T cell exhaustion during persistent viral infections. Virology (2015) 479-480C:180-93. doi:10.1016/j.virol.2014.12.033

77. Gallimore A, Glithero A, Godkin A, Tissot AC, Pluckthun A, Elliott T, et al. Induction and exhaustion of lymphocytic choriomeningitis virus-specific cytotoxic T lymphocytes visualized using soluble tetrameric major histocompatibility complex class I-peptide complexes. J Exp Med (1998) 187(9): 1383-93. doi:10.1084/jem.187.9.1383

78. Klenerman P, Hill A. T cells and viral persistence: lessons from diverse infections. Nat Immunol (2005) 6(9):873-9. doi:10.1038/ni1241

79. Urbani S, Amadei B, Tola D, Massari M, Schivazappa S, Missale G, et al. $\mathrm{PD}-1$ expression in acute hepatitis $\mathrm{C}$ virus (HCV) infection is associated with HCV-specific CD8 exhaustion. J Virol (2006) 80(22):11398-403. doi:10.1128/JVI.01177-06

80. Boni C, Fisicaro P, Valdatta C, Amadei B, Di Vincenzo P, Giuberti T, et al. Characterization of hepatitis B virus (HBV)-specific T-cell dysfunction in chronic HBV infection. J Virol (2007) 81(8):4215-25. doi:10.1128/JVI.02844-06

81. Day CL, Kaufmann DE, Kiepiela P, Brown JA, Moodley ES, Reddy S, et al. PD-1 expression on HIV-specific T cells is associated with T-cell exhaustion and disease progression. Nature (2006) 443(7109):350-4. doi:10.1038/nature05115

82. Jones RB, Ndhlovu LC, Barbour JD, Sheth PM, Jha AR, Long BR, et al. Tim-3 expression defines a novel population of dysfunctional T cells with highly elevated frequencies in progressive HIV-1 infection. J Exp Med (2008) 205(12):2763-79. doi:10.1084/jem.20081398

83. Kaufmann DE, Kavanagh DG, Pereyra F, Zaunders JJ, Mackey EW, Miura T, et al. Upregulation of CTLA-4 by HIV-specific CD4+ T cells correlates with disease progression and defines a reversible immune dysfunction. Nat Immunol (2007) 8(11):1246-54. doi:10.1038/ni1515

84. Tian X, Zhang A, Qiu C, Wang W, Yang Y, Qiu C, et al. The upregulation of LAG-3 on T cells defines a subpopulation with functional exhaustion and correlates with disease progression in HIV-infected subjects. J Immunol (2015) 194(8):3873-82. doi:10.4049/jimmunol.1402176
85. Trautmann L, Janbazian L, Chomont N, Said EA, Gimmig S, Bessette B, et al. Upregulation of PD-1 expression on HIV-specific CD8+ T cells leads to reversible immune dysfunction. Nat Med (2006) 12(10):1198-202. doi:10.1038/nm1106-1329b

86. Day CL, Kiepiela P, Leslie AJ, van der Stok M, Nair K, Ismail N, et al. Proliferative capacity of epitope-specific CD8 T-cell responses is inversely related to viral load in chronic human immunodeficiency virus type 1 infection. J Virol (2007) 81(1):434-8. doi:10.1128/JVI.01754-06

87. Migueles SA, Laborico AC, Shupert WL, Sabbaghian MS, Rabin R, Hallahan CW, et al. HIV-specific CD8+ T cell proliferation is coupled to perforin expression and is maintained in nonprogressors. Nat Immunol (2002) 3(11):1061-8. doi:10.1038/ni845

88. Gaiha GD, McKim KJ, Woods M, Pertel T, Rohrbach J, Barteneva N, et al. Dysfunctional HIV-specific CD8+ T cell proliferation is associated with increased caspase- 8 activity and mediated by necroptosis. Immunity (2014) 41(6):1001-12. doi:10.1016/j.immuni.2014.12.011

89. Mueller YM, De Rosa SC, Hutton JA, Witek J, Roederer M, Altman JD, et al. Increased CD95/Fas-induced apoptosis of HIV-specific CD8(+) T cells. Immunity (2001) 15(6):871-82. doi:10.1016/S1074-7613(01)00246-1

90. MacPherson PA, Fex C, Sanchez-Dardon J, Hawley-Foss N, Angel JB. Interleukin-7 receptor expression on CD8(+) T cells is reduced in HIV infection and partially restored with effective antiretroviral therapy. J Acquir Immune Defic Syndr (2001) 28(5):454-7. doi:10.1097/00042560-200112150-00008

91. Quigley M, Pereyra F, Nilsson B, Porichis F, Fonseca C, Eichbaum Q, et al. Transcriptional analysis of HIV-specific CD8+ T cells shows that PD-1 inhibits T cell function by upregulating BATF. Nat Med (2010) 16(10):1147-51. doi: $10.1038 / \mathrm{nm} .2232$

92. Streeck H, Brumme ZL, Anastario M, Cohen KW, Jolin JS, Meier A, et al. Antigen load and viral sequence diversification determine the functional profile of HIV-1-specific CD8+ T cells. PLoS Med (2008) 5(5):e100. doi:10.1371/ journal.pmed.0050100

93. Wherry EJ, Ha SJ, Kaech SM, Haining WN, Sarkar S, Kalia V, et al. Molecular signature of CD8 $+\mathrm{T}$ cell exhaustion during chronic viral infection. Immunity (2007) 27(4):670-84. doi:10.1016/j.immuni.2007.11.006

94. Blackburn SD, Shin H, Haining WN, Zou T, Workman CJ, Polley A, et al. Coregulation of $\mathrm{CD} 8+\mathrm{T}$ cell exhaustion by multiple inhibitory receptors during chronic viral infection. Nat Immunol (2009) 10(1):29-37. doi:10.1038/ni.1679

95. Kaufmann DE, Walker BD. PD-1 and CTLA-4 inhibitory cosignaling pathways in HIV infection and the potential for therapeutic intervention. J Immunol (2009) 182(10):5891-7. doi:10.4049/jimmunol.0803771

96. Petrovas C, Casazza JP, Brenchley JM, Price DA, Gostick E, Adams WC, et al. $\mathrm{PD}-1$ is a regulator of virus-specific CD8+ T cell survival in HIV infection. J Exp Med (2006) 203(10):2281-92. doi:10.1084/jem.20061496

97. White L, Krishnan S, Strbo N, Liu H, Kolber MA, Lichtenheld MG, et al. Differential effects of IL-21 and IL-15 on perforin expression, lysosomal degranulation, and proliferation in CD8 T cells of patients with human immunodeficiency virus-1 (HIV). Blood (2007) 109(9):3873-80. doi:10.1182/ blood-2006-09-045278

98. Chevalier MF, Julg B, Pyo A, Flanders M, Ranasinghe S, Soghoian DZ, et al. HIV-1-specific interleukin-21+CD4+ T cell responses contribute to durable viral control through the modulation of HIV-specific CD8+ T cell function. J Virol (2011) 85(2):733-41. doi:10.1128/JVI.02030-10

99. Iannello A, Boulassel MR, Samarani S, Debbeche O, Tremblay C, Toma E, et al. Dynamics and consequences of IL-21 production in HIV-infected individuals: a longitudinal and cross-sectional study. J Immunol (2010) 184(1):114-26. doi:10.4049/jimmunol.0901967

100. Spolski R, Leonard WJ. Interleukin-21: a double-edged sword with therapeutic potential. Nat Rev Drug Discov (2014) 13(5):379-95. doi:10.1038/nrd4296

101. Elsaesser H, Sauer K, Brooks DG. IL-21 is required to control chronic viral infection. Science (2009) 324(5934):1569-72. doi:10.1126/science.1174182

102. Johnson LD, Jameson SC. Immunology. A chronic need for IL-21. Science (2009) 324(5934):1525-6. doi:10.1126/science.1176487

103. Aandahl EM, Michaelsson J, Moretto WJ, Hecht FM, Nixon DF. Human $\mathrm{CD} 4+\mathrm{CD} 25+$ regulatory T cells control T-cell responses to human immunodeficiency virus and cytomegalovirus antigens. J Virol (2004) 78(5):2454-9. doi:10.1128/JVI.78.5.2454-2459.2004

104. Eggena MP, Barugahare B, Jones N, Okello M, Mutalya S, Kityo C, et al. Depletion of regulatory T cells in HIV infection is associated with immune activation. J Immunol (2005) 174(7):4407-14. doi:10.4049/jimmunol.174.7.4407 
105. Legrand FA, Nixon DF, Loo CP, Ono E, Chapman JM, Miyamoto M, et al. Strong HIV-1-specific T cell responses in HIV-1-exposed uninfected infants and neonates revealed after regulatory T cell removal. PLoS One (2006) 1:e102. doi:10.1371/journal.pone.0000102

106. Swiecki M, Colonna M. Unraveling the functions of plasmacytoid dendritic cells during viral infections, autoimmunity, and tolerance. Immunol Rev (2010) 234(1):142-62. doi:10.1111/j.0105-2896.2009.00881.x

107. Elahi S, Dinges WL, Lejarcegui N, Laing KJ, Collier AC, Koelle DM, et al. Protective HIV-specific CD8+ T cells evade Treg cell suppression. Nat Med (2011) 17(8):989-95. doi:10.1038/nm.2422

108. Barber DL, Wherry EJ, Masopust D, Zhu B, Allison JP, Sharpe AH, et al. Restoring function in exhausted CD8 T cells during chronic viral infection. Nature (2006) 439(7077):682-7. doi:10.1038/nature04444

109. Jin HT, Anderson AC, Tan WG, West EE, Ha SJ, Araki K, et al. Cooperation of Tim-3 and PD-1 in CD8 T-cell exhaustion during chronic viral infection. Proc Natl Acad Sci U S A (2010) 107(33):14733-8. doi:10.1073/pnas.1009731107

110. Blackburn SD, Shin H, Freeman GJ, Wherry EJ. Selective expansion of a subset of exhausted CD8 T cells by alphaPD-L1 blockade. Proc Natl Acad Sci US A (2008) 105(39):15016-21. doi:10.1073/pnas.0801497105

111. Virgin HW, Wherry EJ, Ahmed R. Redefining chronic viral infection. Cell (2009) 138(1):30-50. doi:10.1016/j.cell.2009.06.036

112. Deng K, Pertea M, Rongvaux A, Wang L, Durand CM, Ghiaur G, et al. Broad CTL response is required to clear latent HIV-1 due to dominance of escape mutations. Nature (2015) 517(7534):381-5. doi:10.1038/nature14053

113. Speiser DE, Utzschneider DT, Oberle SG, Munz C, Romero P, Zehn D. T cell differentiation in chronic infection and cancer: functional adaptation or exhaustion? Nat Rev Immunol (2014) 14(11):768-74. doi:10.1038/nri3740

114. Zehn D, Utzschneider DT, Thimme R. Immune-surveillance through exhausted effector T-cells. Curr Opin Virol (2016) 16:49-54. doi:10.1016/j. coviro.2016.01.002

115. Mylvaganam GH, Rios D, Abdelaal HM, Iyer S, Tharp G, Mavinger M, et al. Dynamics of SIV-specific CXCR5+ CD8 T cells during chronic SIV infection. Proc Natl Acad Sci U S A (2017) 114(8):1976-81. doi:10.1073/pnas. $+1621418114$

116. Li S, Folkvord JM, Rakasz EG, Abdelaal HM, Wagstaff RK, Kovacs KJ, et al. Simian immunodeficiency virus-producing cells in follicles are partially suppressed by CD8+ cells in vivo. J Virol (2016) 90(24):11168-80. doi:10.1128/ JVI.01332-16

117. Ayala VI, Deleage C, Trivett MT, Jain S, Coren LV, Breed MW, et al. CXCR5dependent entry of CD8 T cells into rhesus macaque B-cell follicles achieved through T-cell engineering. J Virol (2017) 91(11):e02507-16. doi:10.1128/ JVI.02507-16

118. Zhou X, Yu S, Zhao DM, Harty JT, Badovinac VP, Xue HH. Differentiation and persistence of memory CD8(+) T cells depend on $\mathrm{T}$ cell factor 1 . Immunity (2010) 33(2):229-40. doi:10.1016/j.immuni.2010.08.002

119. Zhou X, Xue HH. Cutting edge: generation of memory precursors and functional memory CD8+ T cells depends on T cell factor- 1 and lymphoid enhancer-binding factor-1. J Immunol (2012) 189(6):2722-6. doi:10.4049/ jimmunol.1201150

120. Folkvord JM, Armon C, Connick E. Lymphoid follicles are sites of heightened human immunodeficiency virus type 1 (HIV-1) replication and reduced antiretroviral effector mechanisms. AIDS Res Hum Retroviruses (2005) 21(5):363-70. doi:10.1089/aid.2005.21.363
121. Petrovas C, Yamamoto T, Gerner MY, Boswell KL, Wloka K, Smith EC, et al. CD4 $\mathrm{T}$ follicular helper cell dynamics during SIV infection. J Clin Invest (2012) 122(9):3281-94. doi:10.1172/JCI63039

122. Xu H, Wang X, Malam N, Lackner AA, Veazey RS. Persistent simian immunodeficiency virus infection causes ultimate depletion of follicular Th cells in AIDS. J Immunol (2015) 195(9):4351-7. doi:10.4049/jimmunol. 1501273

123. Boritz EA, Darko S, Swaszek L, Wolf G, Wells D, Wu X, et al. Multiple origins of virus persistence during natural control of HIV infection. Cell (2016) 166(4):1004-15. doi:10.1016/j.cell.2016.06.039

124. Grabmeier-Pfistershammer K, Steinberger P, Rieger A, Leitner J, Kohrgruber N. Identification of PD-1 as a unique marker for failing immune reconstitution in HIV-1-infected patients on treatment. J Acquir Immune Defic Syndr (2011) 56(2):118-24. doi:10.1097/QAI.0b013e3181fbab9f

125. Wu T, Ji Y, Moseman EA, Xu HC, Manglani M, Kirby M, et al. The TCF1-Bcl6 axis counteracts type I interferon to repress exhaustion and maintain $\mathrm{T}$ cell stemness. Sci Immunol (2016) 1(6):eaai8593. doi:10.1126/sciimmunol.aai8593

126. Shan L, Deng K, Shroff NS, Durand CM, Rabi SA, Yang HC, et al. Stimulation of HIV-1-specific cytolytic T lymphocytes facilitates elimination of latent viral reservoir after virus reactivation. Immunity (2012) 36(3):491-501. doi:10.1016/j.immuni.2012.01.014

127. Velu V, Titanji K, Zhu B, Husain S, Pladevega A, Lai L, et al. Enhancing SIVspecific immunity in vivo by PD-1 blockade. Nature (2009) 458(7235):206-10. doi:10.1038/nature07662

128. Haran KP, Hajduczki A, Pampusch MS, Mwakalundwa G, VargasInchaustegui DA, Rakasz EG, et al. Simian immunodeficiency virus (SIV)specific chimeric antigen receptor- $T$ cells engineered to target B cell follicles and suppress SIV replication. Front Immunol (2018) 9:492. doi:10.3389/fimmu. 2018.00492

129. Ha SJ, Mueller SN, Wherry EJ, Barber DL, Aubert RD, Sharpe AH, et al. Enhancing therapeutic vaccination by blocking PD-1-mediated inhibitory signals during chronic infection. J Exp Med (2008) 205(3):543-55. doi:10.1084/jem.20071949

130. He R, Yang X, Liu C, Chen X, Wang L, Xiao M, et al. Efficient control of chronic LCMV infection by a CD4 $\mathrm{T}$ cell epitope-based heterologous prime-boost vaccination in a murine model. Cell Mol Immunol (2017):1-12. doi:10.1038/cmi.2017.3

131. Webb GM, Li S, Mwakalundwa G, Folkvord JM, Greene JM, Reed JS, et al. The human IL-15 superagonist ALT-803 directs SIV-specific CD8(+) T cells into B-cell follicles. Blood Adv (2018) 2(2):76-84. doi:10.1182/ bloodadvances. 2017012971

Conflict of Interest Statement: The authors declare that the research was conducted in the absence of any commercial or financial relationships that could be construed as a potential conflict of interest.

Copyright (C) 2018 Xiao, Chen, He and Ye. This is an open-access article distributed under the terms of the Creative Commons Attribution License (CC BY). The use, distribution or reproduction in other forums is permitted, provided the original author(s) and the copyright owner are credited and that the original publication in this journal is cited, in accordance with accepted academic practice. No use, distribution or reproduction is permitted which does not comply with these terms. 